\title{
Local Productive Arrangements and local development in non-metropolitan municipalities of Sao Paulo, Brazil
}

\author{
Arreglos Productivos Locales y desarrollo local en \\ los municipios no metropolitanos \\ de Sao Paulo, Brasil
}

\author{
María Verónica Alderete 1 \\ Miguel Juan BaciC ${ }^{2}$ \\ Universidad Nacional de Sur (Argentina) \\ Universidad Estadual de Campinas (Brasil)
}

Recibido el 6 de julio de 2015, aceptado el 21 de noviembre de 2016

Publicado online el 19 de julio de 2017

$\mathrm{N}^{\circ}$ de clasificación JEL: R11, L23

DOI: $10.5295 / \mathrm{cdg} .150561 \mathrm{ma}$

\begin{abstract}
:
The objective of this paper consists in analysing whether Local Productive Arrangements (APLs) - the Brazilian version of a cluster- can improve the local development of their host municipalities. Most studies concern about the identification and mapping of APL but only a few examine their effects on the socio-economic development of their regions. The major challenge to identifying lessons learned from APL is the lack of robust tools to measure whether or not such policies are successful at local development level. In this line a quantitative research is made to compare the local development among municipalities from the Sao Paulo State, in Brazil by using data from SEADE (Fundação Sistema Estadual de Análise de Dados). Local development is measured by a composite index (IDL) built by the authors and the Sao Paulo State Social Responsibility Index (IPRS). The former includes health and demographic dimensions which are not included in the latter. Municipalities with APL represent about $19 \%$ of the total. Based on analysis of variance, results suggest they have a better local development than municipalities without APL. Since most APLs are relevant for economic local development reasons, they play an important role both for the sectorial policies and for local development policy. This finding would validate the Sao Paulo State policies towards building and consolidation of APL.
\end{abstract}

Keywords:

Clusters, Local Productive Arrangements, local development, socio-economic indicators, non-metropolitan municipalities, Sao Paulo State.

\footnotetext{
${ }^{1}$ Instituto de Investigaciones Económicas y Sociales del Sur (IIESS)-CONICET-UNS. Departamento de Economía, San Andres 800, (8000) Bahía Blanca, Buenos Aires (Argentina). mvalderete@iiess-conicet.gob.ar

${ }^{2}$ Instituto de Economía, Rúa Pitágoras 353, CEP 13083-857 Barão Geraldo, Campinas/SP (Brasil). bacic@eco. unicamp.br
} 


\section{Resumen:}

El objetivo de este trabajo consiste en analizar si los Arreglos Productivos Locales (APL)-la versión brasilera de un cluster- pueden mejorar el desarrollo local de los municipios donde se hospedan. La mayoría de los estudios se preocupa por la identificación y el mapeo de los APL pero sólo unos pocos examinan sus efectos en el desarrollo socio-económico de sus regiones. El mayor desafío de identificar las lecciones aprendidas de los APL es la falta de herramientas robustas para medir si tales políticas son exitosas o no para el desarrollo local. Siguiendo esta línea, se elabora una investigación cuantitativa para comparar el desarrollo local entre los municipios del Estado de San Pablo, Brasil usando los datos de SEADE- Fundación Sistema Estatal de Análisis de Datos. El desarrollo local es medido mediante el Índice Paulista de Responsabilidad Social (IPRS) y un índice compuesto (IDL) construido por los autores. Los municipios con APL representan el 19\% del total en el estado. Los resultados muestran que éstos poseen un mejor desarrollo local comparado a los municipios sin APL. Dado que la mayoría de los APL son relevantes por razones vinculadas al desarrollo económico local, juegan un rol importante tanto para las políticas sectoriales como para la política de desarrollo local. En consecuencia, se convalidarían las políticas para la formación y consolidación de los APL del Estado de San Pablo.

\section{Palabras clave:}

Clusters, Arreglos Productivos Locales, desarrollo local, indicadores socio-económicos, municipios no metropolitanos, Estado de San Pablo. 


\section{INTRODUCTION}

The socio-economic development of a territory seems to be heterogeneous even inside a limited geographic space (Selingardi-Sampaio 2009). The administrative regions are not the most adequate geographical cut since they tend to homogenize geographical areas actually different. Municipalities, even close to each other, can achieve different economic and social indicators. Hence, the Sao Paulo State or other administrative regions cannot be treated as homogenous entities.

A main element to explain the different performance of territories is related to the concept of industrial districts, clusters and local productive systems (Porter 1998; 2003). A set of variables explain the forces of attraction of these territories and their socio-economic paths: population size, urban and logistic infrastructure, industrial parks and public policies. Clusters have become an object of desire for many cities and regions, resting on the widely accepted assumption that increased specialisation will lead to increased level of productivity, growth and employment (Steiner 1998).

Industrial districts (Becattini 1979; Marshall 1980) consist of small firm networks which were able to establish strong positions in markets in a number of traditional product categories. These clusters were fundamental for the economy of Italy. Becattini (1979) explored the economic, social and cultural dynamics that gave birth to the industrial districts.

The cluster concept of Porter is related to a geographical context. Clusters are agglomerations of Small and Medium Sized Enterprises (SME) settled in a particular territory (Porter, 1990). The Brazilian version of a cluster is known as APL- Local Productive Arrangements. RedeSist ${ }^{3}$, in Brazil, has developed the concepts of "local productive arrangements" (APLs) and "local productive and innovative system" in order to study the relationship between groups of firms as well as their linkages with other agents (economic, political and social) within a given territory (Cassiolato and Lastres 2003).

During the last decade, the concept of cluster has acquired a hegemonic presence among the theoretical and empirical trends to explain the importance of the agglomeration process and its relationship with development and competitiveness (Maskell and Kebir 2004). The concept of cluster has changed the regional development perspective to confront with the globalization of the economies (Audrescht 1998; Nooteboom 2006; Salvador Corrales 2007; Spencer et al. 2010).

APLs are basically compound of SME. Focus on SME has been reinforced as these firms influence on the productive structure by building employment and sectorial agglomerations which are a main instrument for the regional development (Crocco et al. 2007). In Brazil, APL is conceived as a policy tool for territorial intervention at three levels: 1) policies at micro, meso and macro spatial scale, 2) the relationship between the concepts of production chain, productive pole and local productive arrangements and 3) the APL role as a local development policy. APLs were built to promote the socio-economic development of their host territories. Therefore, concerns on social inclusion, employment

\footnotetext{
${ }^{3}$ RedeSIst: Rede de Pesquisa em Sistemas e Arranjos Productivos e Inovativos Locais. It is theResearch Networks on Local Productive and Innovative Arrangements and Systems.
} 
and income generation, land distribution, local development, and national integration and frontiers occupation become more evident (Cassiolato et al. 2008).

Industrial districts, Clusters, and APL are all concepts related to agglomeration of SME. However, there are some differences between them. While the concept of cluster is related to a sectorial concentration of connected industries (for instance the cluster of medical devices in the USA), the industrial district necessarily implies a geographical concentration of firms and local institutions. On the other side, although there is not a hierarchical relationship between them, APL could be conceived as a superior instance. Since APL is the agglomeration of firms with economic, political and social actors, it can promote not only production but also innovation through cooperation and learning processes.

Local development is beyond the scope of economic indicators. The economic indicators are not sufficient to explain social progress (Porter et al. 2013). An index of local development would allow to quantify a territory level of "success" in terms of welfare and to compare regions in time and space. Porter et al. (2013) built a social progress index at country level in an attempt to explain social development. Similarly, Penna et al. (2013) analyses the welfare disparities among Brazilian states. Results show that north, northeastern states have a lower welfare level than centre-southern states.

A further analysis of clusters impact evaluation on regional development both theoretical and empirical is needed (Asheim et al. 2006; Leite Filho 2010; Antonialli and Leite Filho 2011). Why some municipalities perform better than other in terms of local development? Do clusters matter to local development? To answer these questions, the characteristics of the region hosting the cluster must be considered.

Studies on the relationship between APL and local development are still incipient in Brazil. Main industrial agglomerations can encourage local development, in conjunction with the support of public and private institutions. They can contribute to improve the quality of life, the productive capacities of individuals and, therefore, explain the development of local productive spaces (Guimaraes and Simões 2004).

The object of study is the Sao Paulo State due to its historic primacy in Brazil and data availability for the identification and mapping of APL (Silva et al. 2010). The historic primacy of the Sao Paulo State in Brazil comes from the convergence of three socioeconomic processes: the coffee production complex; the industrial economy emergence (until 1939) and the effective industrialization. The industrial decentralization from the metropolitan region to the SP interior (Negri 1994) takes place simultaneously to the industrial de-concentration process of SP towards the rest of the country (SEADE 1992). Hence, the SP interior industry prevails over the capital state and the Brazilian industries.

In the Sao Paulo State, Brazil, the Development Secretary is responsible for the APL strengthening and small and medium sized enterprises promotion. In Sao Paulo, the APL policy started in 2004 with the Plurianual Plan. SEBRAE built the APL program to support municipalities (including rural municipalities) with at least one SME arrangement or SME linked to medium and large firms through network systems.

The objective of the present paper consists in examining the influence of clusters on local development through an examination of local productive arrangements in nonmetropolitan and non-metropolitan neighbours municipalities of the Sao Paulo State, Brazil. Most of studies focus on APL identification and mapping, but do not analyse their potential effects on the socio-economic development of their host municipalities. To achieve this 
goal, a local development index is built, using a multivariate analysis, which complements existent measures of development such as the São Paulo State Social Responsibility Index -IPRS. Besides, analysis of variance (ANOVA) is used to compare the development level between municipalities with and without APL.

The paper is structured as follows. At first, a theoretical framework is described. Secondly, the methodology applied is explained. Thirdly, results obtained characterize the municipalities. Finally, final considerations are discussed.

\section{THEORETICAL FRAMEWORK}

The APL analysis has acquired importance as a theoretical and empirical field of study. In Brazil, the emphasis in local leads to the development of the concept of Local Productive Arrangements (Arranjos Produtivos Locais). The concept was developed by the RedeSist (Network of Researchers on Local Innovative and Productive Systems) that uses the term APL and local productive systems to study the relationship between groups of firms and other economic, political and social actors from a specific territory (Cassiolato and Lastres 2003).

These productive arrangements consist of SME agglomerations characterized by vertical relationships and synergic interdependence. They are production systems locally established due to the competitive advantages of the local territory. Local competitive advantages emerge from cooperation and knowledge improvement among firms.

According to SEBRAE (Brazilian Service of Support for Micro and Small Sized Enterprises), APL are the result of agglomeration economies emerging from the geographic proximity of firms in the same territory, with productive specialization, link to each other by a flow of goods and services, and interaction, cooperation and learning processes.

These agglomerations can become engines of international economies as they can serve markets settled in other regions or countries. If clusters compete in cross-regional markets, they are exposed to competition. Anyway, even if they are not traded clusters, local agglomerations can supply services or product to traded clusters. Hence, all of them can drive regional economic competitiveness by encouraging employment, entrepreneurship and innovations in the region. According to the U.S. cluster mapping project, it is useful to view economies through the lens of clusters rather than specific types of companies, industries or sectors because clusters capture the important linkages and potential spillovers of technology, skills, and information that cut across firms and industries (Institute for Strategy and Competitiveness 2014). By participating in global production value chains, dominated by large buyers and/or developed producers, they ensure a linkage with the international market.

The local development approach assumes that local productive systems are a main territorial instrument for the process of growth and the structural changes (Narváez et al. 2008, p.83). Local development is a transformation process of the local economy that improves the inhabitants' quality of life by means of local socio-economic agents (public and private) searching for a more efficient and sustainable resources use (Albuquerque 1997). Three conditions are important for the emergence of a territorial development process: innovation, building networks, and the rational use of existent resources (Caravaca et al. 2005). 
Local Economic Development is a participatory development process that fosters collaborative arrangements between the main public and private actors, enabling the design and implementation of a common development strategy throughout the local resources and competitive advantages, to build employment and stimulate the economic activity (Alburquerque 2004, prologue).

Local development consists of the following dimensions (Gallichio, 2004): economic (building, accumulation and distribution of wealth); social and cultural (quality of life, equity and social integration); environmental (natural resources and sustainability of medium/long-term models) and political (territorial governance, independent and sustainable collective projects).

The industrial organization theory of Marshall (1890) and his concept of organization are main theoretical keys for the local economic development approach since they include the territory as a unit of analysis. A set of development theories, extension of the industrial localization theories, defines a positive relationship between agglomeration and development. Perroux (1955), Myrdal (1957) and Hirschman (1958) assess a cause-effect relationship between the geographic agglomeration of productive activities, especially industrial activities, and the development inequalities in capitalist countries. According to Perroux (1950) development is clearly a local not national phenomenon (Boisier 2005).

The general concept of local development can be applied to different kinds of small territorial areas and human settlements, from local communities to municipalities. Municipal development is a particular case of local development whose area of action is determined by the administrative area of the municipality (Buarque 1999). Therefore, local development is not restricted to municipal development. Sometimes, the local scope includes many municipalities with similar economic, labour and environmental characteristics. Hence, local productive systems borders do not have to coincide with municipal frontiers (Alburquerque 2004).

Cluster firms can develop activities to directly or indirectly achieve the social goals of their local territory (Romis 2007). Some important issues to evaluate are whether cluster firms increase employment among the poorest sectors, reducing social vulnerability, if they promote the accomplishment of social and environmental rules according to the Corporate Social and Environmental Responsibility (CSR). Corporate social responsibility constitutes a strategy to confront new challenges and to promote long term collective initiatives between firms, local and national authorities and the civil society. Hence, CSR becomes an instrument to approach divergent interests and promote local development (Heincke 2005).

Romis (2008) analyses the pro-poor consequences of cluster programs and their potential contribution for social inclusion. Wennberg and Lindqvist (2008) find that cluster firms create more employment, increase tax incomes and offer better wages. However, the impact of these effects depends on the geographical unit under study.

During the last years, the relationship between clusters and regional development have been studied (Braunerhjelm and Borgman 2004; de Blasio and Di Addario 2005; Asheim et al. 2006; Alderete and Bacic 2012). In Brazil, only a few references on the subject are available (Guimaraes and Simões 2004; Ichikawa and Silva 2005; Leite Filho 2010; Leite Filho and Antonialli 2011). Differently to Leite Filho (2010) and Leite Filho and Antonialli (2011) who study APLs from the State of Minas Gerais by using 2006 data, this paper focus on the Sao Paulo State and it uses other development indexes different from the municipal IDH. 
Guimaraes and Simões (2004) examine the relationship between the existence of relevant industrial agglomerations and improvement in socio-economic indicators (population's life condition) in the State of Minas Gerais.

The relationship between industrial agglomerations and socio-economic development depends on the municipality characteristics (Leite Filho 2010; Leite Filho and Antonialli 2011). The socio-economic development improvement, which is measured by the average Human Development Index (IDH) variations, is stronger in medium and small sized municipalities than in large ones. Developing APL or young APL has a significant influence on the local development of that host municipalities which are almost small and medium sized. In contrast, developed APL or advanced APL achieve a high importance for the productive sector but a reduce one for the local development.

This confirms that medium cities have attracted more investments due to their agglomeration economies and advantages for industrial concentration.Inlarge municipalities, industrial concentration can increase the average income but not necessarily the quality of life. In small and medium municipalities, there is a low productive diversification. Hence, an important industrial agglomeration is capable of leading to positive externalities which indeed promote local economic development.

Besides, Ichikawa and Silva (2005) argue that APL can contribute to the sustainable development process, since they emerge as an opportunity to quantitatively and qualitatively increase SME performance.

Their results complement the classification of APL of Suzigan et al. (2003) which identify APL based on specialization and concentration indicators, and propose a typology of APL according to their regional relevance (Table 1).

Table 1

Typology of Productive and Innovative Local Systems (SPIL) according to their regional relevance

\begin{tabular}{|c|c|c|c|}
\hline \multicolumn{2}{|c|}{} & \multicolumn{2}{c|}{ Sectorial relevance } \\
\cline { 2 - 4 } & Low & High \\
\hline \multirow{2}{*}{$\begin{array}{c}\text { Local } \\
\text { Relevance }\end{array}$} & High & Vector of Local development & $\begin{array}{c}\text { Core of sectorial-regional } \\
\text { development }\end{array}$ \\
\cline { 2 - 4 } & Low & Embryo of productive arrangement & Advanced vectors \\
\hline
\end{tabular}

Source: Suzigan et al. (2003, p.12).

\section{METHODOLOGY}

This paper addresses the objective by performing a quantitative research by using the software IBM SPSS Statistics 22. Most studies on local development use a mix of approaches and rarely pretend to quantify the phenomenon. To achieve this goal, a local 
development index is built by using a multivariate analysis, which complements existent measures of development such as the São Paulo State Social Responsibility Index (IPRS).

To build a measure of local development, the explanatory factors of local development provided in the theoretical framework are used as a basis. Table 2 describes the indicators that will be used and provides the references related to each local development dimension.

Table 2

\section{Local development indicators}

\begin{tabular}{|c|c|c|c|}
\hline Dimension & Indicators & Theoretic Variables & Source \\
\hline \multirow{6}{*}{ Economic } & $\begin{array}{c}\text { Per capita Gross Domestic } \\
\text { Product }\end{array}$ & \multirow{6}{*}{$\begin{array}{l}\text { Employment, economic } \\
\text { activity, industrial concentra- } \\
\text { tion, innovation, networks }\end{array}$} & \multirow{6}{*}{$\begin{array}{l}\text { Alburquerque (1997) } \\
\text { Gallichio (2004) } \\
\text { Caravaca et al (2005) } \\
\text { Leite Filho et al (2011) } \\
\text { Suzigan et al (2013) }\end{array}$} \\
\hline & Industry aggregated value & & \\
\hline & $\begin{array}{c}\text { Share of the industry in the } \\
\text { aggregate value }\end{array}$ & & \\
\hline & Exports value & & \\
\hline & $\begin{array}{l}\text { Computers in the direct Mana- } \\
\text { gement of the Town Hall }\end{array}$ & & \\
\hline & $\begin{array}{l}\text { Computers with Internet access } \\
\text { in the Public Administration }\end{array}$ & & \\
\hline \multirow{7}{*}{$\begin{array}{l}\text { Socio- } \\
\text { demographic }\end{array}$} & Birth rate & \multirow{7}{*}{ Quality of life } & \multirow{7}{*}{$\begin{array}{l}\text { Alburquerque (1997) } \\
\text { Gallichio (2004) }\end{array}$} \\
\hline & General mortality rate & & \\
\hline & Sanitary expenditures & & \\
\hline & Health expenditures & & \\
\hline & Education expenditures & & \\
\hline & Primary school rate of approval & & \\
\hline & High school rate of approval & & \\
\hline Environmental & $\begin{array}{c}\text { Environmental Management } \\
\text { expenditures* }\end{array}$ & Sustainable resources use & $\begin{array}{l}\text { Alburquerque } 1997 \\
\text { Gallichio (2004) }\end{array}$ \\
\hline
\end{tabular}

Source: Own elaboration.

Analysis of variance (ANOVA) is used to compare the development level between municipalities with and without APL. The object of study is the non- metropolitan municipalities (excluding metropolitan municipalities and their neighbours) of the Sao Paulo State in Brazil. Metropolitan municipalities are not examined due to their complexity and specific nature: a) Metropolitan regions centralize and perform several productive 
activities. Hence, it is more likely that the reverse causality, from local development to cluster building, will occur in metropolitan regions. b) The de-concentration process of the metropolitan region towards the interior of the São Paulo state. Nowadays, the industrial dispersion is one of the key elements for the São Paulo's restructuring (Lencioni 1998).

This study is based on data from SEADE (Fundação Sistema Estadual de Análise de Dados) that publishes information of the Sao Paulo's municipalities. Since SEADE has only complete data for the year 2004, the local development index built employed indicators of that year. Data for the year 2008 is incomplete ${ }^{4}$.

The APL identification is based on Silva, Bacic and Silveira (2010). The authors made an identification and mapping of APL in the municipalities of São Paulo. Afterwards, by using contingency tables, the study analyses the sectorial distribution of municipalities by type (with APL or without APL). Lastly, the paper compares the socio-economic development indexes between municipalities with APL and municipalities without APL, based on an analysis of variance (ANOVA).

\section{RESULTS DESCRIPTION}

\subsection{Location coefficient: Municipalities’ most relevant economic sector}

Most municipalities develop all type of economic activities from farming and industry, to commerce and services. However, each sector presents a different economic relevance. Hence, a municipality can be assigned its most important economic sector in terms of employment. The assignment is based on the location coefficient which is the share of employment of a sector or economic activity in a specific municipality over the share of employment of the same sector in the Sao Paulo State. The relationship established is:

$$
\mathrm{QL}_{\mathrm{E}}=\frac{\mathrm{E}_{\mathrm{sm}} / \mathrm{E}_{\mathrm{m}}}{\mathrm{E}_{\mathrm{sR}} / \mathrm{E}_{\mathrm{R}}}
$$

Where Esm denotes a municipality's sectorial employment level, Em is a municipality's total employment, Esr the State's sectorial employment level and Er is the State's total employment. The same can be expressed as the share of employment occupied by sector $\mathrm{s}$ in municipality $\mathrm{m}(\mathrm{Esm} / \mathrm{Em})$ over the share of employment of the same sector $\mathrm{s}$ in the State R (EsR/ER). For instance, a location coefficient is the share of employment of the industry in Ubatuba over the share of employment of the industry in the Sao Paulo State. Data corresponds to formal employment published by SEADE.

\footnotetext{
${ }^{4}$ For instance, there is no data about Information and Communication Technologies for the year 2008. Besides, there is missing data in some variables for several municipalities.
} 
Table 3

\section{Sectorial relevance}

\begin{tabular}{|c|c|c|c|}
\hline & Frequency & Percentage & $\begin{array}{c}\text { Accumulated } \\
\text { percentage }\end{array}$ \\
\hline Farming & 105 & 19.4 & 19.4 \\
\hline Commerce & 110 & 20.4 & 39.8 \\
\hline Industry & 162 & 30.0 & 69.8 \\
\hline Services & 163 & 30.2 & 100.0 \\
\hline Total & 540 & 100.0 & \\
\hline
\end{tabular}

Source: Own calculations based on SEADE.

Most non-metropolitan municipalities are of an industrial and services type (nearly 60\%). Commerce and farming follows with 19.4 and $20.4 \%$ respectively (Table 3 ).

Table 4

Distribution of municipalities by economic sector

\begin{tabular}{|c|c|c|c|c|c|}
\hline & & & \multicolumn{3}{|c|}{ Municipality } \\
\hline & & & Without APL & With APL & Total \\
\hline \multirow{10}{*}{ Sector } & \multirow{2}{*}{ Farming } & $\mathrm{N}$ & 65 & 40 & 105 \\
\hline & & $\%$ of Col & $15.0 \%$ & $37.4 \%$ & $19.4 \%$ \\
\hline & \multirow{2}{*}{ Commerce } & $\mathrm{N}$ & 95 & 15 & 110 \\
\hline & & $\%$ of col & $21.9 \%$ & $14.0 \%$ & $20.4 \%$ \\
\hline & \multirow{2}{*}{ Industry } & $\mathrm{N}$ & 151 & 11 & 162 \\
\hline & & $\%$ of col & $34.9 \%$ & $10.3 \%$ & $30.0 \%$ \\
\hline & \multirow{2}{*}{ Services } & $\mathrm{N}$ & 122 & 41 & 163 \\
\hline & & $\%$ of col & $28.2 \%$ & $38.3 \%$ & $30.2 \%$ \\
\hline & \multirow[b]{2}{*}{ Total } & $\mathrm{N}$ & 433 & 107 & 540 \\
\hline & & $\%$ of col & $100.0 \%$ & $100.0 \%$ & $100.0 \%$ \\
\hline
\end{tabular}

Source: Own calculations based on SEADE. 
The study is based on 134 APL in the Sao Paulo state. Municipalities with APL are 107 in total; they represent nearly $19 \%$ of non-metropolitan municipalities in the Sao Paulo State (Table 4). Services and farming municipalities prevail among municipalities with APL, while industrial municipalities predominate among municipalities without APL. This does not suggest that most APL specialized on farming. In fact, only 43 out of 134 APL specialized on agriculture. Most APL are from the industry and services sectors.

\subsection{The Sao Paulo State Social Responsibility Index (IPRS)}

According to SEADE, the Sao Paulo State Social Responsibility Index (IPRS) summarizes each municipality's situation in respect to wealth, scholarity and longevity. Each indicator consist of a linear combination of four variables ${ }^{5}$ expressed in a scale from 0 to 100 , where 100 represents the best situation and 0 the worst. Municipalities can be classified in five groups based on the IPRS index (Table 5).

Table 5

\section{Sao Paulo State Social Responsibility Index (IPRS)}

\begin{tabular}{|c|c|c|}
\hline Groups & Criterions & Description \\
\hline \multirow{4}{*}{ Group 1} & High wealth, medium longevity and medium scholarity & \multirow{4}{*}{$\begin{array}{l}\text { Municipalities characterized by } \\
\text { a high level of wealth, with good } \\
\text { social indicators levels. }\end{array}$} \\
\hline & High wealth, medium longevity and high scholarity & \\
\hline & High wealth, high longevity and medium scholarity & \\
\hline & High wealth, high longevity and high scholarity & \\
\hline \multirow{5}{*}{ Group 2} & High wealth, low longevity and low scholarity & \multirow{5}{*}{$\begin{array}{l}\text { Municipalities, even with high } \\
\text { wealth, are not capable of } \\
\text { reaching good social indicators } \\
\text { levels. }\end{array}$} \\
\hline & High wealth, low longevity and medium scholarity & \\
\hline & High wealth, low longevity and high scholarity & \\
\hline & High wealth, medium longevity and low scholarity & \\
\hline & High wealth, high longevity and low scholarity & \\
\hline \multirow{4}{*}{ Group 3} & Low wealth, medium longevity and medium scholarity & \multirow{4}{*}{$\begin{array}{l}\text { Municipalities with low wealth } \\
\text { levels, but good social indicators. }\end{array}$} \\
\hline & Low wealth, medium longevity and high scholarity & \\
\hline & Low wealth, high longevity and medium scholarity & \\
\hline & Low wealth, high longevity and high scholarity & \\
\hline
\end{tabular}

\footnotetext{
${ }^{5}$ Variables that compound the index a) Wealth: residential consumption of electric energy; consumption of electric energy in agriculture, commerce and services; mean remuneration of employees in the public sector; per capita fiscal added value; b) Longevity: perinatal mortality; child mortality; Adults between 15 and 39 years old mortality; Adults between 60 or more mortality; c) Scholarity: percentage of young between 15 and 17 years that finished primary school; percentage of young between 15 and 17 years with at least 4 years of schooling; percentage of young between 18 and years that finished high school; percentage of child between 5 and 6 years in pre-school.
} 


\begin{tabular}{|c|c|c|}
\hline \multirow{4}{*}{ Group 4} & Low wealth, low longevity and medium scholarity & \multirow{4}{*}{$\begin{array}{l}\text { Municipalities with low wealth } \\
\text { levels and intermediate levels of } \\
\text { longevity and scholarity. }\end{array}$} \\
\hline & Low wealth, low longevity and high scholarity & \\
\hline & Low wealth, medium longevity and low scholarity & \\
\hline & Low wealth, high longevity and low scholarity & \\
\hline Group 5 & Low wealth, low longevity and low scholarity & $\begin{array}{l}\text { Disadvantaged Municipalities } \\
\text { both in wealth and social indi- } \\
\text { cators. }\end{array}$ \\
\hline
\end{tabular}

Source: SEADE, Fundação Sistema Estadual de Análise de Dados 2011.

\subsection{IPRS comparison of municipalities with and without APL}

Table 6

Average IPRS according to type of municipality

\begin{tabular}{|c|c|c|c|c|}
\hline Type of municipality & IPRS 2004 & IPRS 2009 & $\mathrm{N}$ & St. Dev \\
\hline With APL & 3.10 & 3.25 & 107 & 1.344 \\
\hline Without APL & 3.47 & 3.61 & 433 & 1.048 \\
\hline Total & 3.40 & 3.54 & 540 & 1.125 \\
\hline
\end{tabular}

Source: Own calculations based on SEADE.

Considering that IPRS groups vary from 1 (best situation, position) to 5 (worst position), it can be observed that municipalities with APL attain on average a better IPRS than the rest of municipalities (Table 6). The result is robust to the index used; the statistical significance of the difference is sustained using IPRS2004 or IPRS2009 (Table 7).

Table 7

ANOVA

\begin{tabular}{|c|c|c|c|c|c|c|}
\hline & & $\begin{array}{c}\text { Sum of } \\
\text { squares }\end{array}$ & $\mathrm{fd}$ & $\begin{array}{c}\text { Quadratic } \\
\text { Media }\end{array}$ & F & Sig. \\
\hline IPRS 2004 & Inter-groups & 8,214 & 1 & 8,214 & 6,996 &, 008 \\
\hline & Intra-groups & 631,629 & 538 & 1,174 & & \\
\hline IPRS 2009 & Total & 639,843 & 539 & & &, 002 \\
\hline & Inter-groups & 10,957 & 1 & 10,957 & 9,772 & \\
\hline & Intra-groups & 603,226 & 538 & 1,121 & & \\
\hline
\end{tabular}

Source: Own calculations using SPSS. 


\subsection{Local development Index built}

To test the robustness of the hypothesis that the presence of APL positively influence on local development, an alternative local development index to the IPRS was built. This index includes socio-demographic variables which are not introduced in the IPRS, such as Health and sanitary expenditures, and mortality and birth rates. Besides, two alternative local development indexes are built: IDL1 and IDL2. IDL2 excludes computers or ICT indicators and includes environmental expenditures.

A composite index of local development is built. Composite indexes are quantitative and qualitative measures made of a set of characteristics that evidence relative positions in a particular topic. Some advantages of composite indexes are communication, trend representation (reducing the number of indicators), aggregation of complex and multidimensional issues, and instrument for decision makers (Rocha 2009).

The study employs a multivariate analysis to build a composite index that summarizes the information from indicators available for each municipality. A factorial analysis is a descriptive technique to identify a relatively small number of factors representing the existent relationship among a set of interrelated variables. The objective of principal component analysis (PCA) consists in finding a set of factors that explain the maximum total variance of the original variables. The PCA method determines a linear combination of the whole variables such that the first principal component explains the largest share of the variance, the second the second largest share of the variance (simultaneously uncorrelated with the first component), and so on. After that, factors are rotated to simplify the factor structure and make its interpretation easier and more reliable. The most popular rotation method is Varimax (Kaiser 1958). For Varimax a simple solution means that each factor has a small number of large loadings and a large number of zero loadings. After Varimax rotation, each original variable can be associated with one (or a small number) of factors, and each factor represent a small number of variables (Abdi 2003). Following, the paper explains how indexes were built.

\subsubsection{Local Development Index 1(IDL1)}

Table 8

\section{Communalities}

\begin{tabular}{|c|c|c|}
\hline & Initial & Extraction \\
\hline Education expenditures & 1,000 &, 881 \\
\hline Sanitary expenditures & 1,000 &, 391 \\
\hline Health expenditures & 1,000 &, 903 \\
\hline Exports value & 1,000 &, 556 \\
\hline Primary school rate of approval & 1,000 &, 640 \\
\hline High school rate of approval & 1,000 &, 636 \\
\hline Industry aggregated value & 1,000 &, 835 \\
\hline
\end{tabular}


Local Productive Arrangements and local development in non-metropolitan municipalities of Sao Paulo, Brazil

\begin{tabular}{|c|c|c|}
\hline Share of the industry in the aggregate value & 1,000 &, 657 \\
\hline Per capita Gross Domestic Product & 1,000 &, 663 \\
\hline Computers in the direct Management of the Town Hall & 1,000 &, 384 \\
\hline Computers with Internet access in the Public Administration & 1,000 &, 429 \\
\hline Birth rate & 1,000 &, 266 \\
\hline
\end{tabular}

Extraction method: Principal component analysis.

Source: Own calculations using SPSS.

Table 9

\section{Rotated components matrix}

\begin{tabular}{|c|c|c|c|}
\hline & \multicolumn{3}{|c|}{ Component } \\
\hline & 1 & 2 & 3 \\
\hline Education expenditures & ,921 & ,082 &,- 071 \\
\hline Sanitary expenditures & ,705 &,- 072 &, 012 \\
\hline Health expenditures & 946 & 033 &,- 027 \\
\hline Exports value & ,766 &, 172 & ,026 \\
\hline Primary school rate of approval & ,065 &,- 037 & ,781 \\
\hline High school rate of approval &,- 030 &,- 013 & ,793 \\
\hline Industry aggregated value & ,872 &, 312 &,- 004 \\
\hline Share of the industry in the aggregate value &, 170 & ,789 &,- 096 \\
\hline Per capita Gross Domestic Product &, 158 & ,790 &, 062 \\
\hline $\begin{array}{l}\text { Computers in the direct Management of the Town } \\
\text { Hall }\end{array}$ & ,926 & ,036 &,- 055 \\
\hline $\begin{array}{l}\text { Computers with Internet access in the Public Admi- } \\
\text { nistration }\end{array}$ & 685 &, 158 &,- 085 \\
\hline Birth rate &, 130 &, 170 &,- 641 \\
\hline General mortality rate &, 014 &,- 529 &, 159 \\
\hline
\end{tabular}

Extraction method: Principal component analysis. Rotation method: Varimax normalization with Kaiser. IBMSPSS 20. Rotation converges in 5 iterations.

Source: Own calculations using SPSS. 
Information from communalities (Table 8) shows that some variables acquire a low relevance for explaining the variance (communality lower than 0.4 ), such as sanitary expenditures, demographic growth rates and computers with internet access.

The Development Index components are listed in (Table 9). Indicators in bold explain the corresponding dimension (education expenditures explains component 1 , but not component 2 or 3 ).

\subsubsection{Local Development Index 2 (IDL 2)}

Contrary to the Local development Index 1, the IDL2 (Table 10) does not include variables concerning ICT (such as computers in the direct management of Town Hall or computers with Internet access) and includes an environmental indicator.

Table 10

\section{IDL 2 Communalities}

\begin{tabular}{|c|c|c|}
\hline & Initial & Extraction \\
\hline Education expenditures & 1,000 &, 875 \\
\hline Environmental Management expenditures & 1,000 &, 705 \\
\hline Sanitary Expenditures & 1,000 &, 766 \\
\hline Health expenditures & 1,000 &, 893 \\
\hline Exports value & 1,000 &, 640 \\
\hline Primary School approval rate & 1,000 &, 640 \\
\hline High school approval rate & 1,000 &, 660 \\
\hline Share of industry in total aggregated value & 1,000 &, 354 \\
\hline General mortality rate & 1,000 &, 678 \\
\hline Per capita Gross Domestic Product & 1,000 &, 915 \\
\hline Industry aggregate value & 1,000 &, 430 \\
\hline
\end{tabular}

Extraction method: Principal component analysis.

Source: Own calculations using SPSS.

Table 11

Rotated components matrix

\begin{tabular}{|c|c|c|c|}
\hline \multirow{2}{*}{} & \multicolumn{3}{|c|}{ Component } \\
\cline { 2 - 4 } & $\mathbf{9 0 6}$ & \multicolumn{1}{|c|}{3} \\
\hline Education expenditures & $\mathbf{9 0 6}$ &,- 055 \\
\hline Environmental Management expenditures & $\mathbf{, 6 2 7}$ &,- 190 &,- 047 \\
\hline Sanitary Expenditures & $\mathbf{, 6 7 9}$ &,- 157 &,- 061 \\
\hline Health expenditures & $\mathbf{9 2 8}$ &, 140 &,- 013 \\
\hline
\end{tabular}


Local Productive Arrangements and local development in non-metropolitan municipalities of Sao Paulo, Brazil

\begin{tabular}{|c|c|c|c|}
\hline Exports value & $\mathbf{6 6 7}$ &, 372 &, 073 \\
\hline Primary School approval rate &, 068 &,- 067 & $\mathbf{7 9 0}$ \\
\hline High school approval rate &,- 044 &,- 037 &, 043 \\
\hline Share of industry in total aggregated value &, $\mathbf{7 8 2}$ &, 490 &,- 119 \\
\hline General mortality rate &, 102 &, 754 &, 113 \\
\hline Per capita Gross Domestic Product &, 027 & $\mathbf{- , 4 7 6}$ & $\mathbf{- , 6 3 5}$ \\
\hline Industry aggregate value &, 080 &, 116 &, 004 \\
\hline
\end{tabular}

Extraction method: Principal component analysis. Rotation method: Varimax normalization with Kaiser. IBMSPSS 20. Rotation converges in 5 iterations.

Source: Own calculations using SPSS.

Following the methodology, the components obtained for building the development index are listed in (Table 11):

To summarize,IDL1 excludes some socio-demographic variables (sanitary expenditures, computers with internet, and mortality rate) based on the communalities, while IDL 2 only excludes the mortality rate.

Table 12 provides a statistical summary for each development index indicator.

Table 12

\section{Descriptive statistics}

\begin{tabular}{|c|c|c|c|c|c|}
\hline & $\mathrm{N}$ & Min & Max & Media & St. Dev \\
\hline Education Expenditures* & 540 & 0 & 349821636 & 9179463,08 & 24679917,411 \\
\hline $\begin{array}{l}\text { Environmental Manage- } \\
\text { ment expenditures* }\end{array}$ & 540 & 0 & 26535875 & 195315,52 & 1533149,688 \\
\hline Sanitary expenditures* & 540 & 0 & 158951739 & 1987892,34 & 9904055,356 \\
\hline Health expenditures* & 540 & 0 & 419614938 & 8309956,39 & 28955351,601 \\
\hline Exports value+ & 540 & 0 & 3081702245 & 24059822,82 & 150604520,486 \\
\hline High school approval rate & 540 & 59,90 & 100,00 & 84,4907 & 7,09823 \\
\hline $\begin{array}{c}\text { Primary school approval } \\
\text { rate }\end{array}$ & 540 & 74,20 & 100,00 & 92,6356 & 4,32636 \\
\hline Industry aggregate value & 540 & 1 & 6462 & 116,59 & 414,876 \\
\hline
\end{tabular}




\begin{tabular}{|c|c|c|c|c|c|}
\hline $\begin{array}{c}\text { Industry share in total } \\
\text { aggregate value }\end{array}$ & 540 & 4,60 & 84,54 & 22,7769 & 15,04353 \\
\hline $\begin{array}{c}\text { Per capita Gross Domes- } \\
\text { tic Product }\end{array}$ & 540 & 2641 & 109963 & 10251,30 & 8865,475 \\
\hline General Mortality rate & 540 & 2,42 & 13,28 & 6,4907 & 1,46212 \\
\hline Birth rate & 540 & 4,26 & 24,85 & 13,7989 & 3,14543 \\
\hline $\begin{array}{c}\text { Computers in the direct } \\
\text { management of the Town } \\
\text { Hall }\end{array}$ & 540 & 0 & 2030 & 63,58 & 152,051 \\
\hline $\begin{array}{l}\text { Computers with Internet } \\
\text { access in the Town Hall }\end{array}$ & 540 & 1 & 400 & 26,83 & 47,474 \\
\hline $\mathrm{N}$ valid (according to list) & 540 & & & & \\
\hline
\end{tabular}

* In reales of 2012 (Brazilian pound); **, in millions current reales, +in dollars FOB.

Source: Own calculations based on SEADE.

Table 13

\section{Comparison of average indexes by type of municipality}

\begin{tabular}{|c|c|c|c|}
\hline Type of municipalities & & IDL1 & IDL2 \\
\hline \multirow{2}{*}{ Without APL } & Media & 0,213125 & 0,202357 \\
\cline { 2 - 4 } With APL & St. dev. & 0,0440425 & 0,0575703 \\
\hline \multirow{2}{*}{ Total } & Media & 0,232902 & 0,211768 \\
\cline { 2 - 4 } & St. dev & 0,0605582 & 0,0588758 \\
\hline \multirow{2}{*}{ Wedia } & 0,217194 & 0,204293 \\
\cline { 2 - 4 } & St. dev & 0,0485101 & 0,0579133 \\
\hline
\end{tabular}

Source: Own calculations using SPSS.

Municipalities with APL attain a higher local development index than municipalities without APL (Table 13) as much for IDL1 as IDL2. However, this difference is not statistically significant for IDL2 (Table 14).

The ANOVA technique is used to analyse the effect of different levels of a single factor on a normally distributed variable. Assuming IDL1 to be normally distributed with common variance, the hypothesis at the $1 \%$ significance level that there is no difference between municipalities with and without APL with respect to mean IDL1 is rejected. 
Table 14

Analysis of Variance ( ANOVA)

\begin{tabular}{|c|c|c|c|c|c|c|}
\hline & & Sum of squares & gl & Quadratic media & F & Sig. \\
\hline \multirow{3}{*}{ IDL1 } & Inter-groups & 0,036 & 1 & 0,036 & 15,578 & 0,000 \\
\cline { 2 - 7 } & Intra-groups & 1,277 & 539 & 0,002 & & \\
\cline { 2 - 7 } & Total & 1,313 & 540 & & & \\
\hline \multirow{3}{*}{ IDL2 } & Inter-groups & 0,008 & 1 & 0,008 & 2,418 & 0,121 \\
\cline { 2 - 7 } & Intra-groups & 1,863 & 539 & 0,003 & & \\
\cline { 2 - 7 } & Total & 1,872 & 540 & & & \\
\hline
\end{tabular}

Note: The association measures Square Eta are 0,027 and 0,004 for IDL1 and IDL2 respectively.

Source: Own calculations using SPSS.

\section{RESULTS AND CONCLUSIONS}

This study is a part of the few attempts to quantitatively analyse the relationship between APL identification and local development. The objective of this paper consists in determining if Local Productive Arrangements (APL) can be an instrument to improve the local development of their host municipalities.

The literature on productive arrangements has historically tended to focus on issues related to the competitiveness of firms based on the economic advantages that clustering could engender (Alderete and Bacic 2012). However, researchers and policymakers often omit the fact that in many cases APL can overcome some social problems such as unemployment, lack of education, and poverty, among others.

This study focuses on non-metropolitan municipalities of the Sao Paulo State, in Brazil. The identification of local productive arrangements in Sao Paulo was based on Silva et al (2010). By means of a quantitative analysis, results show that most of municipalities are committed to industry and services (60\%). On the other side, municipalities with APL represent nearly $19 \%$ of the sample. Only 43 out of 134 APLs specialized on agriculture. Most APL are from the industry and services sectors and are mostly hosted by services and farming municipalities (based on the location coefficient).To measure local development, two indexes were used as proxy indicators: the Sao Paulo State Social Responsibility Index (IPRS) and a local development index (IDL) built by the authors. Differently to the IPRS, the IDL covers some additional socio-demographic variables. As a result, municipalities with APL present, on average, a better development level than municipalities without APL as much for the IPRS (3.10 is-a-vis 3.47) as the Local development index IDL1 built (0.23 vis-a-vis 3.47). Based on the analysis of variance, differences on the local development indexes are statistically significant. Hence, APLs would lead to a better local development. 
APLs have been of interest for governments and experts in Brazil in order to better allocate actions to promote local development. Since most APLs are relevant for economic local development reasons, they play an important role both for the sectorial policies and for local development policy. In this sense, results support SEBRAE and any other institutions' actions to promote APL building and competitiveness. APL policy can engender better economic and social indicators to host municipalities or regions. These policies are not only important to the surviving and competitiveness of APL, but also directly impact the local development.

The major challenge to identifying lessons learned from APL is the lack of robust tools to measure whether or not such policies are successful at local development level.

During the last years, most of the countries have implemented policies to support SME. Among these policies, those focusing on industrial agglomerations and production chains have prevailed. The main weakness of Latin American policies is the lack of an integrated and coherent vision about the development and competitive progress of local SME. Any initiative to intensify the competitive progress of local SME should adopt an integrated vision. Besides, since resources are scarce, policies should promote those industrial agglomerations which are strategic for the regional competitiveness and local development. From a policy point of view, the results obtained in this paper validate the Sao Paulo State institutional actions towards building and consolidation of APL. On the future, it would be useful to test the analysis using other local development indexes.

\section{REFERENCES}

Abdi, H., 2003. Factor rotations in factor analyses. In: Lewis-Beck M., Bryman, A., Futing T. eds. Encyclopedia of Social Sciences Research Methods. Thousand Oaks (CA): Sage. Alburquerque, F., 1997. Desarrollo económico local y distribución del progreso técnico.

Una respuesta a las exigencias del ajuste estructural. Cuadernos ILPES, 43, 1-118.

Albuquerque, F., 2004. Desarrollo económico local y descentralización en América Latina. Revista de la CEPAL, 82, 157-171.

Alderete, M.V. and Bacic, M.J., 2012. The impact of inter-firm networks on regional development: the case of Mendoza's wine cluster. Lecturas de Economía, 76, 171- 213. Araujo, E. and Pinto da Rocha, E., 2009. Trajetória da Sociedade da Informação no Brasil: Proposta de Mensuração por Meio de um Indicador Sintético. Ciencia da Informação, 38(3), 9-20.

Asheim, B., Cooke, P.; and Martin, R. 2006. Clusters and Regional Development: Critical Reflections and Explorations. New York: Routledge.

Audretsch, D. B. and Feldman, M., 1996. R\&D spillovers and the geography of innovation and production. American Economic Review, 86 (3), 630-640.

Audretsch, D. B., 1998. Agglomeration and the Location of Innovative Activity. Oxford Review of Economic Policy, 14 (2), 18-29.

Becattini, G., 1979. Dal settore industriale Al distretto industriale. Rivista di Economia e Politica Industriale, Italy, Franco Angely, N 1.

Boisier, S., 2005. ¿Hay espacio para el desarrollo local en la globalización?. Revista de la CEPAL, 86, 45-62. 
Braunerhjelm, P., and Borgman, B., 2004. Geographical concentration, entrepreneurship and regional growth: Evidence from regional data in Sweden, 1975-99. Regional Studies, 38, 929-947.

Buarque,S. 1999. Metodología de planejamento do desenvolvimento local e municipal sustentable. Recife, Brasil: Instituto Interamericano de Cooperación para la Agricultura (IICA).

Caravaca, I., González, G., and Silva, R. Innovación, redes, recursos patrimoniales y desarrollo territorial. Revista Eure, 21 (94), 5-24.

Cassiolato, J., Lastres, H. and Stallivieri, F., 2008. Arranjos produtivos locais. Uma alternativa para o desenvolvimento. Experiencias de política, 2. Rio de Janeiro: Editora E-papers Serviços Editoriais Ltda. RedeSist.

Cassiolato, J. E., and Lastres, H. M. M., 2003. O foco em arranjos produtivos e inovativos locais de micro e pequenas empresas. In: Lastres, H. M. M., Cassiolato, J. E., and Maciel, M. orgs. Pequena empresa: cooperação e desenvolvimento local. Relume Dumará, São Paulo, 21-34.

Crocco, M. A. et al., 2007. Indicadores para identificação de arranjos produtivos locais. Disponível em: <www.redisist.ie.ufrj.br>.

De Blasio, G., and Di Addario, S., 2005. Do workers benefit from industrial agglomeration? Journal of Regional Science, 45 (4), 797-827.

Gallicchio, E., 2004. El desarrollo local en América Latina. Estrategia política basada en la construcción de capital social. Seminario Desarrollo con inclusión y equidad: sus implicancias desde lo local, SEHAS, Córdoba (Argentina).

Guimaraes Rodriguez, C. and Simões, R., 2004.Aglomerados industriais e desenvolvimento socioeconômico: uma análise multivariada para Minas Gerais. Ensaios FEE, Porto Alegre, 25 (1), 203-232.

Hirschman, A.O., 1958. The strategy of economy development. New Haven, CT: Yale University Press.

Ichikawa, R. A. and Silva, R. S., 2005. Arranjos produtivos locais: uma alternativa de empreendimento rumo ao desenvolvimento sustentável. Caderno De Administração, 13 (2), 13-23.

Institute for Strategy and Competitiveness, 2014. The US cluster mapping project. USA: Harvard Business School.

Lastres, H., 2007. Avaliação das políticas de promoção de arranjos produtivos locais no Brasil e proposição de ações. RedeSist, Rio de Janeiro.

Leite Filho, G.A. and Antonialli, L.M., 2011. Proposta de classificação de arranjos produtivos locais por indicadores de identificação: um estudo multivariado. Interações, Campo Grande, 12(1), 53-64.

Leite Filho, G.A., 2010. Classificação de Arranjos Produtivos Locais por indicadores de identificação: Um estudo multivariado. XXXIV Encontro da ANPAD. Rio de Janeiro, RJ, September 25- 29.

Lencioni, S., 1998. Reestruturação urbano-industrial no Estado de São Paulo: a região da metrópole desconcentrada. In: Santos, M., A De Souza, M.A, and Silveira M.L. Territorio. Globalização e fragmentação. São Paulo.

Marshall, A., 1980. The principle of economics. London: Macmillan, 1972. First published.

Maskell, P. and Kebir, L., 2004. What qualifies as a Cluster Theory?. Danish Research Unuit Industrial Dynamics (DRUID), Working Paper 05-09. 
Myrdal, G. 1957. Economic theory and underdeveloped regions. London: Duckworth.

Narváez, M., Fernández, G., and Senior, A. 2008. El desarrollo local sobre la base de la asociatividad empresarial: una propuesta estratégica. Opción, 24(57),74 - 92.

Negri, B., 1994. Concentração e desconcentração industrial em São Paulo (1880-1990). Thesis (PhD in Economics)- Instituto de Educação, UNICAMP, Campinas, 1994.

Nooteboom B., 2006. Innovation, learning and cluster dynamics. In: Asheim B., Cooke P, Martin R., eds. Clusters and regional development: critical reflections and explorations. Abingdon: Routledge, 137-163.

Penna, C., Linhares, F., Carvalho, E., and Trompieri Net, N., 2013. Análise das disparidades de Bem-estar entre os estados do Brasil. Estudos Económicos, 43 (1), 51-78.

Perroux, F., 1955. Note sur la notion de pole de croissance. Economie Appliqué, 8(1-2), 302-320.

Porter, M. E., 1990. The Competitive Advantage of Nations. New York: Free Press.

Porter, M.E., 1998. On Competition. Boston, MA: Harvard Business School Press.

Porter, M. E., 2003. The economic performance of regions. Regional Studies, 37 (6), 549578.

Porter, M., Stern, S., and Artavia Loría, R., 2013. Social Progress Index 2013. A publication of the Social Progress Imperative.

Romis, M., 2007. Competitiveness of small enterprises: clusters, business environment and local development. Synthesis of the international meeting held at the Inter-American Development Bank on October 29-30, Washington, D.C.

Salvador Corrales, C., 2007. Importancia Del cluster em el desarrollo regional actual. Frontera Norte, 19 (37), 173-201.

SEADE- Fundacao Sistema Estadual de Análise de Dados, 1992. Cenários da urbanização paulista. Regioes administrativas. Colecao São Paulo no limiar do Século XXI. São Paulo: Governo do Estado de São Paulo.

SEADE, Fundacao Sistema Estadual de Análise de Dados. In www.seade.gov.br

Selingardi-Sampaio, S., 2009. Indústria e território em São Paulo. A estruturação do Multicomplexo Territorial Industrial Paulista 1950-2005. Campinas, Brasil: Ed. Alínea.

Silva, A. L. G., Bacic, M. J., and Silveira, R. L. F., 2010. Análise das políticas para arranjos produtivos locais no Estado de São Paulo. In: Campos, R.R., Stavallieri, F., Vargas, M.A. ,Matos, M., org. Políticas Estaduais para Arranjos Produtivos Locais no Sul, Sudeste e Centro-Oeste do Brasil. Rio de Janeiro : E-papers, 139-182.

Spencer G, Vinodrai T, Gertler M, Wolff D., 2010. Do clusters make a difference? Defining and assessing their performance. Regional Studies, 44(6), 697-715.

Stallivieri, F., 2011. Indicadores para Arranjos Produtivos Locais. Technical note 5 (preliminary version). Elements for building an APL typology Project. In www. desenvolvimento.gov.br

Steiner, M., 1998. Clusters and regional specialisation: On Geography, technology and networks. London: Pion.

Suzigan, W., Furtado, J., Garcia, R., and Sampaio, S. E. K., 2003. Aglomerações industriais no Estado de São Paulo. Instituto de Economia: UNICAMP.

Wennberg, K. and Lindqvist, G., 2010. The effect of clusters on the survival and performance of new firms. Small Business Economics, 34 (3), 221-241. 
